\title{
An investigation on the effect of central bank money injection on creating currency crisis
}

\author{
Nazi Mohamadzadeh Asl ${ }^{\mathrm{a}}$ and Leila Jamshidi ${ }^{\mathrm{b}^{*}}$
}

${ }^{a}$ Associate Professor, Department of Economic and Accounting, Tehran Central Branch, Islamic Azad University, Tehran, Iran

${ }^{b}$ Masters in Economic Sciences, Tehran Central Branch, Islamic Azad University, Tehran, Iran

\section{H R O N I C L E}

\section{Article history:}

Received October 28, 2013

Received in revised format

25 November 2013

Accepted 29 January 2014

Available online

February 82014

Keywords:

Currency crisis

Logit and Probit models

Government liabilities

\section{A B S T R A C T}

\begin{abstract}
This paper investigates the effects of different factors influencing on supplement of currency in Iran and the likelihood of currency crises. The study implements two methods of Logit to determine the likelihood of currency crises based on the historical data over the period 19892012. In this study, currency crisis is defined in terms of three variables of currency change on market, interest rate and central bank foreign deposits. The results of the study indicate that the ratio of government (non-government) liabilities to central bank/Growth domestic product (GDP) has positive (negative) relationship with currency crises.
\end{abstract}

(C) 2014 Growing Science Ltd. All rights reserved.

\section{Introduction}

Currency crisis is one of the most important issues in modern economies and there are various studies on learning different factors influencing currency crises (Kruger et al., 2000; Brüggemann \& Linne, 2002; Gunsel et al., 2010). Frankel and Rose (1996), for instance, applied a panel of annual data for over 100 developing countries from 1971 to 1992 in order to investigate currency crashes. They defined a currency crash as a large change of the nominal exchange rate, which was also a substantial increase in the rate of change of nominal depreciation. They examined the composition of the debt as well as its level, and other macroeconomic external and foreign factors. They reported that crashes take place when output growth becomes low; the growth of domestic credit and the level of foreign interest rates increase. For many years, many researchers have claimed success in systematically forecasting which countries are more likely to suffer currency crises, most notably Kaminsky, Lizondo and Reinhart (1998) method called KLR approach. Berg and Pattillo (1999) evaluated the KLR approach to anticipating currency crises, developed and examined an alternative.

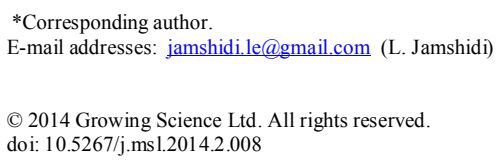


Goldfajn and Valdés (1998) studied whether exchange rate expectations and overvaluations were predictors of currency crises and reported that overvaluation had predictive power in describing the crises. Lestano and Jacobs (2004) compared different currency crisis dating techniques adopting various definitions of currency pressure indexes and ad-hoc and extreme value based thresholds. Marchesi (2003) examined the existence of an empirical relationship between the adoption of an IMF program and the concession of a debt rescheduling by commercial creditors based on a bivariate probit model. The study confirmed the existence of a significant impact of the adoption of an IMF program on the subsequent concession of a debt rescheduling by private creditors. Burkart and Coudert (2002) identified common features of currency crises in 15 emerging countries based on quarterly data over the period 1980-1998. They applied Fisher's linear discriminant analysis to construct an early-warning system. Fratzscher (2003) analyzed the role of contagion in the currency crises in emerging markets during the 1990s. The study used a non-linear Markov-switching framework to compare three distinct causes of currency crises including contagion, weak economic fundamentals, and sunspots. They reported that in particular the degree of financial interdependence and real integration among emerging markets were crucial not only in explaining past crises but also in forecasting the transmission of future financial crises.

\section{The proposed study}

This paper investigates the effects of different factors influencing on supplement of currency in Iran and the likelihood of currency crises. The study implements two methods of Logit to determine the likelihood of currency crises based on the historical data over the period 1989-2012. In this study, currency crisis is defined in terms of three variables of currency change on market, interest rate and central bank foreign deposits. The dependent variable is a dummy variable, which receives a value one if the currency encounters crisis and zero, otherwise. The crisis is defined as follows,

$$
\text { Crisis }=\left\{\begin{array}{ccc}
1 & \text { if } & \text { EMPI }>1.5 \sigma_{\text {EMPI }}+\mu_{E M P I} \\
0 & \text { otherwise }
\end{array}\right.
$$

The study adopts exchange market pressure index (EMPI) from the study developed by Lestano and Jacobs (2004) as follows,

$$
\mathrm{EMPI}_{\mathrm{T}}=\frac{\Delta e_{t}}{e_{t}}-\frac{\sigma_{e}}{\sigma_{r}} \frac{\Delta r_{t}}{r_{t}}+\frac{\sigma_{e}}{\sigma_{i}} \Delta i_{t},
$$

where $e_{t}$ represents actual rate of currency, $\sigma_{e}$ is standard deviation of central bank foreign currency deposit, $r_{t}$ stands for foreign currencies and $\sigma_{r}$ is standard deviation. Finally, $\sigma_{i}$ represents standard deviation in inflation rate with $\triangle i_{t}=i_{t}-i_{t-1}$. Let $B B D$ be the ratio of governmental loans to banks on growth domestic product (GDP), $B B G D$ be the ratio of non- governmental loans to banks on growth domestic product (GDP), $Z A M$ and $Z A B$ be the net value of foreign assets in central bank and other banks, respectively. The Logit regression model used by the proposed study is as follows,

$$
\operatorname{logit}(\mathrm{p})=\ln \frac{p}{1-p}=z=\beta_{0}+\beta_{1} B B D+\beta_{2} B B G D+\beta_{3} Z A M+\beta_{4} Z A B .
$$

Any change on the likelihood of occurrence is calculated as follows,

$\frac{\partial p}{\partial x}=\frac{e^{\beta x}}{\left(1+e^{\beta x}\right)^{2}} \beta_{i}=p(1-p) \beta_{i}$.

In addition, the elasticity to change in likelihood of crisis is calculated as follows, 
$e_{k}=\left(\frac{e^{\beta x}}{\left(1+e^{\beta x}\right)^{2}} \beta_{i}\right) \frac{x}{p}=(1-p) \beta_{i} x_{i k}$.

Next, we present details of our findings on performing regression analysis.

\section{The results}

In this section, we present details of our findings on the implementation of the regression function. Table 1 demonstrates the results of our findings.

\section{Table 1}

The summary of regression analysis

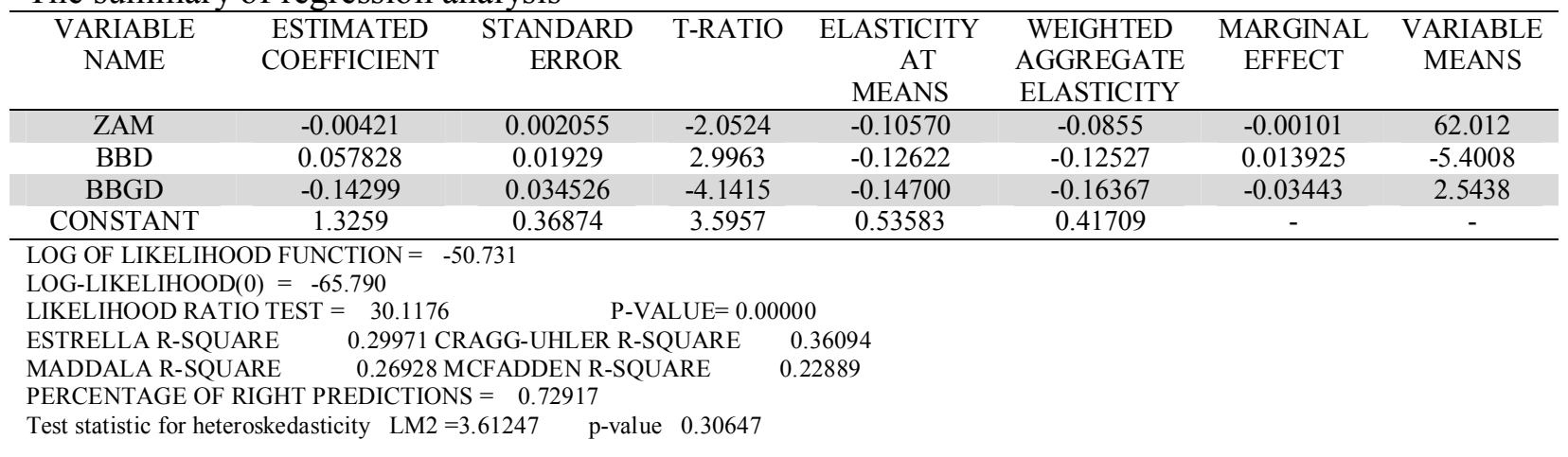

As we can observe from the results of Table 1, Likelihood ration test is equal to 30.1176 , which is meaningful when the level of significance is one percent. In addition, t-student values are statistically significant for all coefficients. The positive sign of BBD $\left(\beta_{1}=0.057828\right)$ indicates that as government receives more loans from the central bank, the likelihood of currency crisis increases. In addition, the negative sign of BBDG $\left(\beta_{2}=-0.14299\right)$ indicates that as the ratio of non- governmental loans to banks on growth domestic product (GDP) increases, the likelihood of currency crisis decreases.

\section{Conclusion}

One of the most important issues in developing countries is have stable currency. When currency loses its value, the whole economy goes under uncertainty. Many people purchase foreign currencies trying to protect themselves from currency de-evaluation. Therefore, it is important to find important factors influencing currency crisis and take necessary action against it. In this paper, we have presented an empirical investigation to find out more about the effect of government liabilities towards central banks. The study indicates that as the government receives financial assistance from the government, the chances of facing currency crisis increases. In addition, as the ratio of nongovernmental loans to banks on growth domestic product (GDP) increases, the likelihood of currency crisis decreases.

\section{Acknowledgement}

The authors would like to thank the anonymous referees for constructive comments on earlier version of this paper.

\section{References}

Berg, A., \& Pattillo, C. (1999). Predicting currency crises: The indicators approach and an alternative. Journal of International Money and Finance, 18(4), 561-586. 
Burkart, O., \& Coudert, V. (2002). Leading indicators of currency crises for emerging countries. Emerging Markets Review, 3(2), 107-133.

Brüggemann, A., \& Linne, T. (2002). Are the Central and Eastern European Transition Countries Still Vulnerable to a Financial Crisis?: Results from the Signals Approach (No. 5/2002). Bank of Finland, Institute for Economies in Transition.

Fratzscher, M. (2003). On currency crises and contagion. International Journal of Finance \& Economics, 8(2), 109-129.

Frankel, J. A., \& Rose, A. K. (1996). Currency crashes in emerging markets: An empirical treatment. Journal of international Economics, 41(3), 351-366.

Goldfajn, I., \& Valdés, R. O. (1998). Are currency crises predictable?. European Economic Review, 42(3), 873-885.

Gunsel, N. R., Tursoy, T., \& Rjoub, H. (2010). An empirical analysis of currency crises, fundamentals and speculative pressure. African Journal of Business Management, 4(6), 972-978.

Hensher, D. A., \& Johnson, L. W. (1981). Applied discrete choice modelling. Wiley.

Kaminsky, G., Lizondo, S., \& Reinhart, C. M. (1998). Leading indicators of currency crises. Staff Papers-International Monetary Fund, 1-48.

Kruger, M., Osakwe, P. N., \& Page, J. (2000). Fundamentals, contagion and currency crises: an empirical analysis. Development Policy Review, 18(3), 257-274.

Lestano, L., \& Jacobs, J. (2004). A comparison of currency crisis dating methods: East Asia 19702002 (No. 200412). University of Groningen, CCSO Centre for Economic Research.

Marchesi, S. (2003). Adoption of an IMF programme and debt rescheduling. An empirical analysis. Journal of Development Economics, 70(2), 403-423. 